International Journal of Trend in Scientific Research and Development (IJTSRD)

Volume: 3 | Issue: 4 | May-Jun 2019 Available Online: www.ijtsrd.com e-ISSN: 2456 - 6470

\title{
Study About Effects of Oblique Angle of Die Surface to the Product Quality in the Deep Drawing
}

\author{
Nguyễn Văn Quảng, Phạm Văn Liệu \\ Faculty of Mechanical Engineering, Hanoi University of Industry, Hanoi, Vietnam
}

\begin{abstract}
How to cite this paper: Nguyen Van Quang | Pham Van Lieu "Study About Effects of Oblique Angle of Die Surface to the Product Quality in the Deep Drawing" Published in International Journal of Trend in Scientific Research and Development (ijtsrd), ISSN: 24566470, Volume-3 | Issue-4, June 2019, pp.528-531, URL: https://www.ijtsrd. com/papers/ijtsrd2 3860.pdf

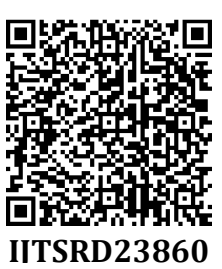

Copyright (C) 2019 by author(s) and International Journal of Trend in Scientific Research and Development Journal. This is an Open Access article distributed under the terms of the Creative Commons

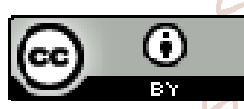
Attribution License (CC BY 4.0) (http://creativecommons.org/licenses/ by $/ 4.0$ )

\section{ABSTRACT}

Deep drawing is one of the special methods for the sheet metal forming in the pressure processing field. This method is applied to manufacture the mechanical products with the deep and complex shapes. The influences of oblique angle of die surface to the product quality of the metallic forming are diccussed. This study uses the Abaqus software to simulate for four cases of the oblique angle of the die surface in the sheet metal forming processes. With each the simulation cases, the result shows that the wall thickness, material distribution and forming pressure are different for each various products. Moreover, the simulation results support a useful data table for the research and manufacturing in the deep drawing field.

Keywords: Abaqus software; Deep drawing; Sheet metal; Product quality; Oblique angle

\section{INTRODUCTION}

Deep drawing is one of the most popular and widely used sheet metal working processes and is used for producing cups from sheet metal at a very high rate. The deep drawing process is affected by many design parameters, such as blank shape, formability characteristics of material, blank holder force and clearance between punch and die, etc. The forming process deforms the shape, dimesion and the status of the sheet metal by the direct impact force to form up the nescessery shape and dimesion products such as the circle, parallelepiped and complex shape [1-5].

Many researches performed for the deep drawing technology because this method is adropted to form the effectly sheet metal. The deep drawing process is affected by many design parameters such as blank shape, formability characteristics of material, blank holder force and clearance between punch and die, etc. In the drawing process, blank holder and die geometry are very important formability factors for obtaining the optimal products [6-10].

Most of the effective fators which impact to the deep drawing were studied. Howover, the parameters as the effects of oplique angles of blank holder and die surface to the product quality in deep drawing have superficial researched. Therefore, the main objective of this research will concentrate to discuss for the various cases about manitudes of oplique angles of blank holder and die surface to give out the most optimization in the sheet metal forming.

\section{MODEL AND RESEARCH METHOD}

2.1. Research model

Model of deep drawing process is a combination of die, blank, blank holder and punch as Fig. 1

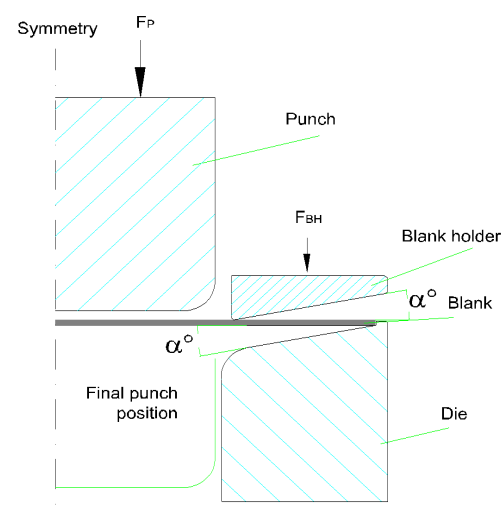

Fig 1. Deep drawing model 
International Journal of Trend in Scientific Research and Development (IJTSRD) @ www.ijtsrd.com eISSN: 2456-6470

The simulation parameters using the finite element model are described in Table 1, including the model dimension and physical quantities.

Table 1. Dimensions and parameters table of finite element model

\begin{tabular}{|c|c|}
\hline Blank diameter $\left(\mathrm{D}_{\mathrm{b}}\right)$ & $100 \mathrm{~mm}$ \\
\hline Blank thickness $(\mathrm{t})$ & $1 \mathrm{~mm}$ \\
\hline Punch diameter $\left(\mathrm{D}_{\mathrm{p}}\right)$ & $50 \mathrm{~mm}$ \\
\hline Clearance between punch and die $(\mathrm{C})$ & $1.1 \mathrm{~mm}$ \\
\hline Draw depth $(\mathrm{d})$ & $25 \mathrm{~mm}$ \\
\hline Punch force $\left(\mathrm{F}_{\mathrm{p}}\right)$ & $60 \mathrm{KN}$ \\
\hline Friction coefficient between punch and blank & 0.015 \\
\hline Friction coefficient between die and blank & 0.015 \\
\hline Friction coefficient between blank holder and blank & 0.015 \\
\hline
\end{tabular}

\subsection{Research method}

This study used the finite element method to establish the mesh for the simulation model. The sheet metal is diviced in many small elements which is connected by the common nodes. We only need simulate and analyse for all these elements which can get the exact and detailed results more than the biggest model.

Abaqus software is adropted to perform the simulations in this research. The obtained results show the obvious effects of technologies as blank holder and oblique die angle to the quality of the deep drawing products.

In the drawing process, the sheet metal is subjected the influences of the along and cross axis tensile stresses. In addition, the compression stress of blank holder also impacts on the metallic sheet.

Value of the punch force [11] is calculated by formula (1).

$$
F_{p}=\Pi \cdot d \cdot t \cdot\left(\sigma_{T S}\right) \cdot\left(\frac{D}{d}-0.7\right)
$$

Which: $\mathrm{d}=$ Punch diameter

$\mathrm{D}=$ Blank diameter

$\mathrm{t}=$ Blank thichkness

$\sigma_{\mathrm{Ts}}=$ ultimate tensile stress of material

The magnitude of the blank holder force [12] is calculated by formula (2).

$$
\mathrm{F}_{\mathrm{BH}}=\frac{\pi}{4}\left[\mathrm{D}^{2}-\left(\mathrm{d}_{\mathrm{p}}-2 \mathrm{R}_{\mathrm{p}}\right)^{2}\right], \mathrm{P}_{\mathrm{d}}
$$

Which: $\mathrm{D}=$ Blank diameter

$\mathrm{D}_{\mathrm{p}}=$ Product inside diameter

$\mathbf{R}_{\mathrm{p}}=$ Punch radius

$\mathrm{t}=$ Blank thickness

$\mathrm{P}_{\mathrm{c}}=(2.04 \div 5.1) \mathrm{MPa}$ is blank holder pressure

\section{RESULTS AND DISCUSSION}

Four cases of the oblique die angles are studied in this paper. The parameters of each case are provided to establish the simulation model as in table 2 .

Table 2. Cases of the finite element simulation in deep drawing.

\begin{tabular}{|c|c|c|c|c|c|c|c|}
\hline Cases & $\begin{array}{c}\text { Oblique angle } \alpha \\
\text { (degree) }\end{array}$ & $\begin{array}{c}\text { Clearences } \\
\mathbf{C}(\mathbf{m m})\end{array}$ & $\begin{array}{c}\text { Punch radius } \\
\mathbf{R}_{\text {punch }}(\mathbf{m m})\end{array}$ & $\begin{array}{c}\text { Die radius } \\
\mathbf{R}_{\text {die }}(\mathbf{m m})\end{array}$ & $\begin{array}{c}\text { Blank holder } \\
\mathbf{F}_{\text {BH }}(\mathbf{N})\end{array}$ & $\begin{array}{c}\text { Friction } \\
\text { coefficient } \mu\end{array}$ & $\begin{array}{c}\text { Punch velocity } \\
\mathbf{V}_{\mathbf{p}}(\mathbf{m} / \mathbf{s})\end{array}$ \\
\hline 1 & $0^{\circ}$ & 1.1 & 5 & 5 & 3000 & 0.15 & 0.13 \\
\hline 2 & $5^{\circ}$ & 1.1 & 5 & 5 & 600 & 0.15 & 0.13 \\
\hline 3 & $10^{\circ}$ & 1.1 & 5 & 5 & 600 & 0.15 & 0.13 \\
\hline 4 & $15^{\circ}$ & 1.1 & 5 & 5 & 600 & 0.15 & 0.13 \\
\hline
\end{tabular}

The quality of the drawing product is appreciated through two criteria which are the same wall thickness and and surface quality of the drawing product. The measurement positions show as in Fig. 2.

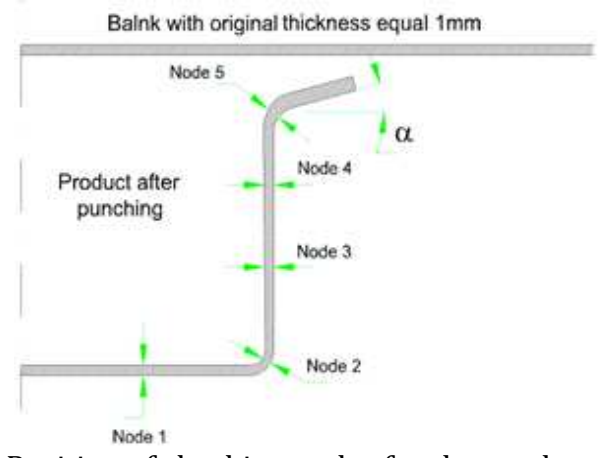

Fig. 2. Position of checking nodes for the product thickness 
International Journal of Trend in Scientific Research and Development (IJTSRD) @ www.ijtsrd.com eISSN: 2456-6470

From the simulation results, with the same value of other parameters which a constant value of deep drawing ratio is as formula (3).

$$
\beta=\frac{D_{b}}{D_{p}}=\frac{100}{\mathrm{~s} 0}=2
$$

We have the graph of relation between oblique die angle ?a? ?and blank holder force $\left(F_{\mathbb{B H}}\right)$ as Fig. 3.

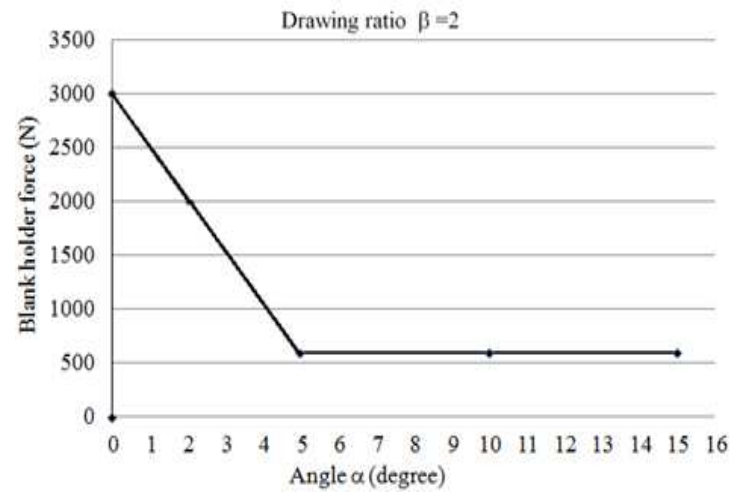

Fig.3. Influence of ? ?die angle on blank holder force

Fig.3. shows that the value of blank holder force is decreased from $3000(\mathrm{~N})$ to $600(\mathrm{~N})$ when value of oblique angle of die surface (? ? ?increases from 0 degree to 5 degree. And when increasing the ? from 5 degree to 15 degree, the blank holder force is a constant value of $600(\mathrm{~N})$. Therefore, the value of blank holder force is converged when angle (?? ? ? is equal or exceeded 5 degree. This result presents that the angle (? ? ? has influenced on blank holder force with the most optimal value of $600(\mathrm{~N})$. This is the evidence which improves the influence of oblique angles of die surface to magnitude of blank holder force.

The model of deep drawing products obtained from the simulation results with oblique angle of die surface in the order of $0^{\circ}$, $5^{\circ}, 10^{\circ}$ and $15^{\circ}$ respectively as shown in Fig. 4 (a), (b), (c), and (d).

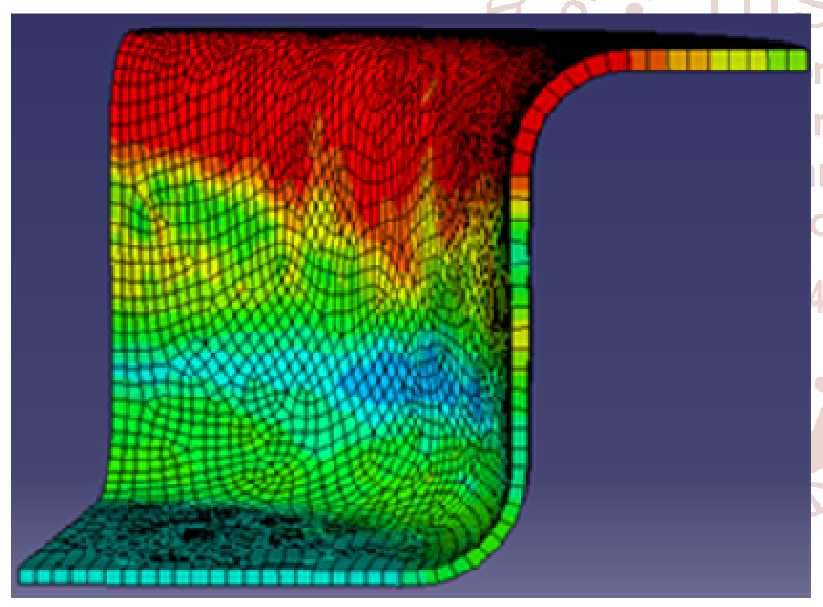

(a)

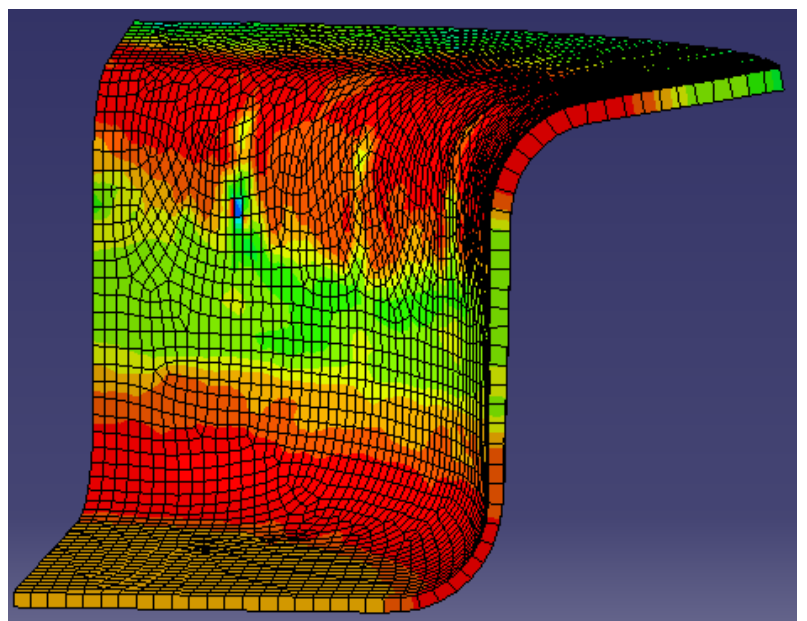

(c)

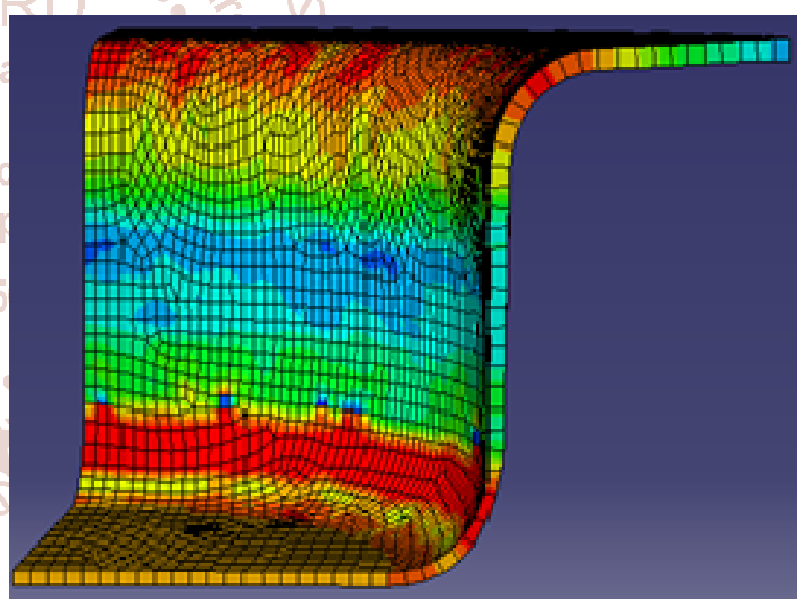

(b)

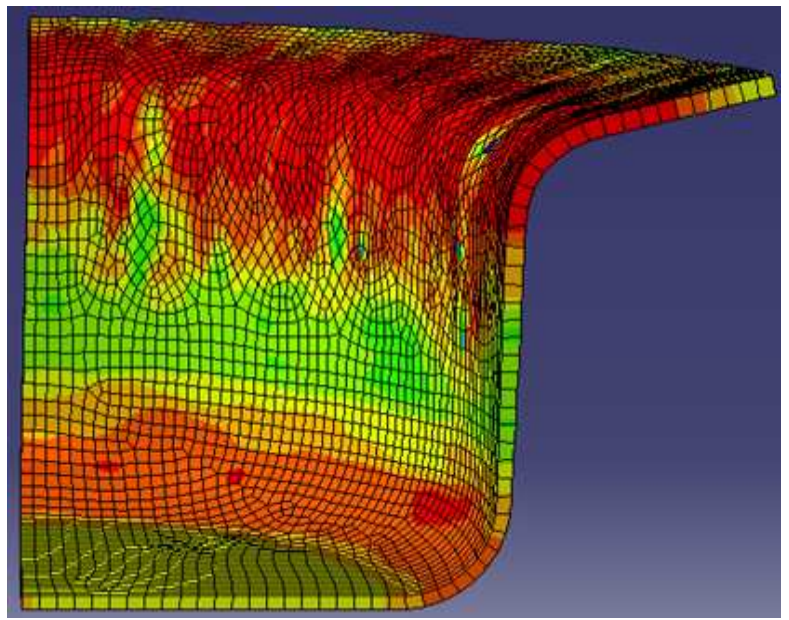

(d)

Fig. 4. The model of deep drawing products with oblique angle of die surface in the order of: a) $0^{\circ}$; b) $5^{\circ}$; c) $10^{\circ}$ và d) $15^{\circ}$ 
Graphic presents the wall thickness of product which measures from the position of node 1 to the node 5 showing as in Fig.5.

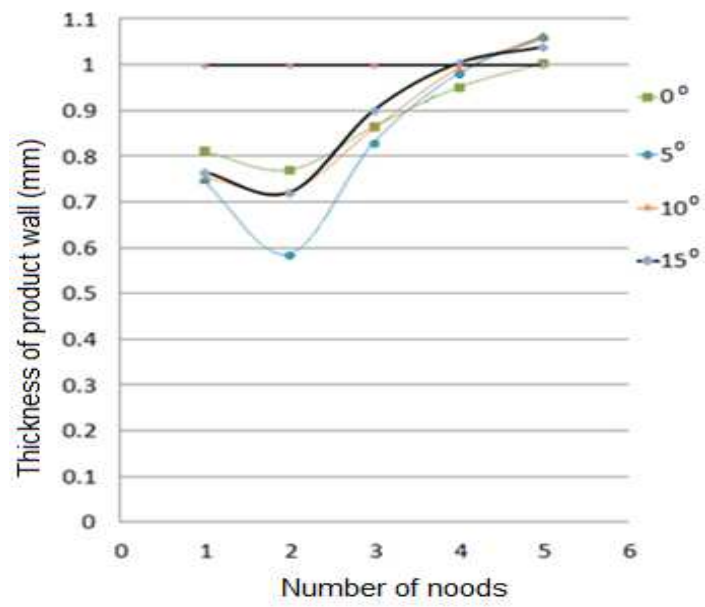

Fig.5. Thickness of drawing product wall

Plots in the Fig.5 show that the thicknesses of the obtained product wall are diferent for each various oblique angle cases of the die surface. The wall thickness reduces the center to around position of product bottom. In addition, the wall thicknesses increase from the position of node 1 to the node 5 .

This research performs simulation for the four cases of oblique angles of die surface and blank holder. The obtained results are used to analysis, compare and discuss which purposes to take out the most optimal parameter. The criteria about the plastic competence, surface quality and thickness of regular product wall are used to appreciate and choose the most suitable parameters for obtaining the best quality of the drawing product.

Comparision for the plots in Fig.5 and models in Fig.4 which shows that the thickness of product wall are the least transformable and the same original blank thickness with the oblique angle case of $0^{\circ}$. Howover, the plastic competence and surface quality of the simulation product are poor than other cases. Otherwise, the blank holder of this case is $3000 \mathrm{~N}$ which is greeter than the blank holder of remained cases.

With the all obove results, the oblique angle case of $15^{\circ}$ is the most satisfactory for the requirement criteria as the plastic competence, surface quality and thickness of regular product wall. The best product model is shown in Fig.6.

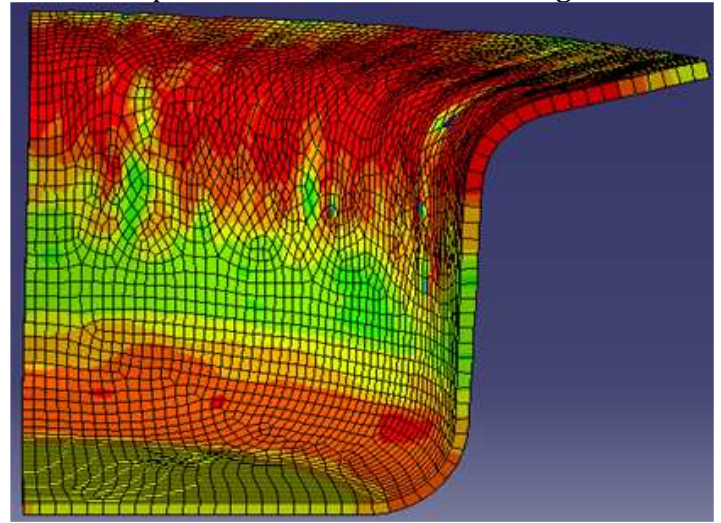

Fig.6. The model of deep drawing product with oblique angle of die surface of $15^{\circ}$
Fig. 6 is the best simulation result of four research cases about the oblique angle of die surface. The blank holder of $600 \mathrm{~N}$ is the least use in this case. Moreover, the surface quality of simulation product is better in compareision with other cases. Therefore, the oblique angle of die surface of $15^{0}$ the most suitable value to adopt for the deep drawing of the sheet metal. The research parameter of this case can refer and apply in the experiment works and the real manufacturing.

\section{CONCLUSION}

The four cases of the oblique angle of die surface and blank holder were studied in this paper. The obtained results were used to analysis, compare and discuss which purposes to take out the most optimal parameter base on the requirement criteria. The optimal parameter can be refered and applied in the experiment works and the real manufacturing.

Through the simulation performance, the results show that the blank holder force decreases form $3000 \mathrm{~N}$ to $600 \mathrm{~N}$ when the oblique angle of die surface increases from $0^{\circ}$ to $15^{\circ}$.

The blank holder is a constant when the oblique angle of die surface is greater or equal $5^{\circ}$.

With the oblique angle of die surface and blank holder is $0^{\circ}$ which the thickness of product wall are the least transformable with the oblique angle case of $0^{\circ}$. Howover, the plastic competence and surface quality of the simulation product are poor and the blank holder is the greatest of 3000 $\mathrm{N}$.

Therefore, the oblique angle of die surface of $15^{0}$ the most suitable case to use for the deep drawing of the sheet metal which can obtain the product quality as the requirement criteria and the blank holder is the lowest of $600 \mathrm{~N}$.

\section{REFERENCES}

[1] Trương Tích Thiện, 2007. Lý thuyết dẻo kỹ thuật. NXB đại học quốc gia TP HCM.

[2] Nguyễn Mậu Đằng. Công nghệ tạo hình kim loại tấm, NXB khoa học và kỹ thuật Hà Nội.

[3] V. L. Martrenco, L. I Rudman. Sổ tay thiết kế khuôn dập tấm, NXB Hải Phòng.

[4] B. Wassilieff, Emboutissage, người dịch Nguyễn Ngọc, 1981. NXB công nhân kỹ thuật Hà Nội.

[5] Lê Nhương, 1981. Kỹ thuật dập nguội, NXB công nhân kỹ thuật Hà Nội.

[6] Swift W, Chung SY, 1951. Cup drawing from a flat blank experimental investigation. Proc Int Mech Eng.

[7] Danckert J, 1995. Reduction of residual stress in deep drawing by modeling the draw die profile. Ann CIRP.

[8] Fereshteh-Saniee F, Montazeran MH, 2003. A comparative estimation of the forming load in the deep drawing process. J Mater Process Technol.

[9] Korhonen AS, 1982. Drawing force in deep drawing of cylindrical cup with flat-nosed punch. J Eng Ind.

[10] K. Hanaki, K. Kato, 1984. Pressure peak in bending and unbending process, Adv. Technol. Plastic.

[11] V. Boljanovic, 2004. Sheet metal forming processes and die design, New York 10016.

[12] H. E. Theis, 1999. Handbook of Metal Forming Processes, New York, NY 10016 